\title{
Transition of Ralstonia Mannitolilytica From Commensal to Pathogen During Hospitalization: A Catheter Related Bloodstream Infection (CRBSI) Case Caused by R. Mannitolilytica Colonized in The Respiratory Tract
}

Keywords:

Posted Date: September 23rd, 2020

DOl: https://doi.org/10.21203/rs.3.rs-68792/v2

License: (c) (i) This work is licensed under a Creative Commons Attribution 4.0 International License.

Read Full License 


\section{Abstract}

The authors have requested that this preprint be removed from Research Square. 